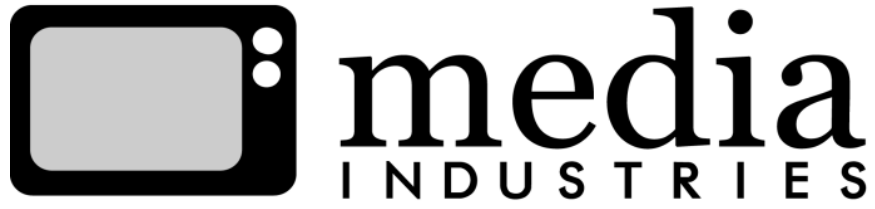

\section{Mobile Production: Spatialized Labor, Location Professionals, and the Expanding Geography of Television Production}

\author{
Myles McNutt ${ }^{1}$ \\ University of Wisconsin-Madison \\ mamcnutt [AT] wisc.edu
}

\begin{abstract}
:
This article addresses the spatial challenges facing television laborers amid an increasingly expansive and contingent environment of local production incentives. Pushing away from the term runaway production and its limited engagement with local, spatialized dynamics of labor, I argue for a consideration of "mobile production," wherein television series are capable of being executed in an increasingly wide range of locations-not necessarily Los Angeles-and capable of being moved should changes in an incentive system create the need to do so. Through personal interviews and analysis of industry discourse, this case study of location professionals considers how the mobility of production affects below-the-line local laborers. Mobile production relies on location workers more than any other job category, but the capacities of these workers are geographically specific: while they make the globalized mobile production apparatus viable, they are also the most likely to be left behind if incentive structures shift and Hollywood producers "go mobile" and move on.
\end{abstract}

Keywords: Labor, Television, Production, United States, Localism

In July 2014, the Wilmington Star News featured a report on Brooke Barnhill, a location manager for the CBS drama series Under the Dome (2013-), which filmed its first and second seasons in and around Wilmington in 2013 and 2014. ${ }^{2}$ The Barnhill piece was part of the paper's larger interest in covering the series and the local film and television industry on its Wilm on Film blog and elsewhere. ${ }^{3}$ The Star's coverage mirrors the local-angle reporting on the film and television industry seen in other cities where production incentives have helped lure major film and television productions, as the subject holds interest for those wishing to either see their city onscreen or, potentially, those who want to enter the industry themselves.

As a distinct artifact, however, the Barnhill article offers two important insights into the relationship between television production and local communities. The first is that Barnhill, as a location manager, is one of the workers with the strongest ties to the region. As the person responsible for finding, contracting, and managing locations, her job requires both an intense 
knowledge of Wilmington and the surrounding area as well as a strong working relationship with local community groups. This relationship developed over the thirteen years she worked on locations for television series like Dawson's Creek (1998-2003) and One Tree Hill (2003-2012). The second insight is that Barnhill consciously framed her comments relative to the future of the North Carolina production incentives that made her work on those series possible, and which during the summer of 2014 were in the process of being dismantled. In August, Governor Pat McCrory eliminated the existing 25 percent tax rebate and replaced it with a capped grant system. This meant that ongoing television series like Under the Dome would likely lose millions of dollars in incentives if they continued to shoot in the state. Quoted by the Star News in its overview of the impact this change would have on production, Wilmington Film Commission director Johnny Griffin boiled it down to a simple notion: "I don't care how much somebody likes you and loves you, they are not coming going to come here and spend 25 percent more than they can spend somewhere else." 4

This notion has been at the heart of discussions of "runaway production" and the proliferation of incentive programs drawing television production to new locations. While British Columbia and North Carolina were among the early major competitors of Los Angeles and New York, in the past decade, states like Georgia and New Mexico have developed aggressive incentive packages that have dramatically expanded the landscape of North American television production. However, this expansion is inherently tenuous, dependent as it is on political and economic developments that are at times unpredictable. While North Carolina has drawn a consistent stream of television production over the past decade, recent change in state tax incentives dramatically altered the economics of shooting in the state. This led at least one production -Cinemax's Banshee (2013-) - to announce plans to move elsewhere once the change was made official. Reports also speculated that both Under the Dome and Fox's Sleepy Hollow (2013-) would likely relocate should they be picked up for third seasons. The new grant program immediately threatened the consistent, ongoing employment that has made hour-long dramatic television series like these the "holy grail" for emerging production centers. ${ }^{5}$

This article addresses the challenges facing below-the-line laborers amid an increasingly expansive and contingent environment of local production incentives in the context of television production. Pushing away from the term runaway production and its limited engagement with local dynamics of labor in emerging media capitals, I argue for a consideration of "mobile production," wherein television series are capable of being planted in an increasingly wide range of locations - not necessarily centered in Los Angeles - and capable of relocating should changes in an incentive system create the need to do so. Specifically, this article focuses on how this new geography of production emphasizes the spatial dynamics of contemporary television labor, focusing its attention on location professionals. These below-the-line workers are the most crucial to supporting mobile production, serving as an interface between the global apparatus of the media industries and local resources and institutions. While their work makes the globalized mobile production apparatus viable, the skills they develop are geographically specific. This means that the mobility that reaffirms the value of their labor simultaneously makes them the most likely to be left behind if incentive structures shift and the Hollywood producers move on. Through personal interviews and analysis of industry trade discourse, I argue that mobile production has created this and other spatialized workforces. These workforces are expected to make personal and professional sacrifices to mobilize their labor in order to ensure long-term employment in an expansively contingent-and mobile-period in television production. 


\section{Moving Past Runaway Production}

Researchers historically have framed the expansion of television production outside of Los Angeles as a problem of runaway production, exploring the political-economic moves and countermoves that have shaped the map of media production over the past century. Peter Hall traces the very origins of Hollywood to "runaway" productions originally based in New York and Chicago, while Greg Elmer and Mike Gasher point to the dissolution of the studio system as a "push" factor in increasing location shooting outside of Hollywood.6 In Global Hollywood 2, Toby Miller et al. consider the "new international division of cultural labor" that media corporations have embraced in an effort to reduce costs and take advantage of an increasingly globalized media landscape. ${ }^{7}$ Such runaway production can, according to Aida A. Hozic, be seen as "the symptom of 'footloose corporations,' or an era in which an unprecedented mobility of capital and production has enabled corporations to constantly seek-and find-friendlier and friendlier business environments." 8 As Miller et al. observe, there is an inherent unpredictability to such flows of capital. Acknowledging that the new international division of cultural labor "relies on cultural consanguinity, favorable rates of exchange, supine governments, minimal worker internationalism and high levels of skill equivalency," they ultimately conclude that "it is real," and confront it as one of the most significant shifts in the political economy of creative industries. ${ }^{9}$

Building on this work, scholarly considerations of media research have confronted runaway production from two primary positions. The first, drawing on the political economy tradition, considers how increases in runaway production-most often tied to production incentives offered by a given country, state, province, or territory - are altering the macrolevel economy of the creative industries as well as the economies of the cities, regions, or countries in question. Within this tradition, focused case studies consider the economic impact on existing centers of media production such as Los Angeles along with aspiring media capitals such as Louisiana, Michigan, and North Carolina, which seek to "pull" production using incentives. ${ }^{10}$ These analyses have proved crucial to understanding the dramatic reshaping of the map of media production based on government subsidies and increasingly mobile capital, and for evaluating the impact of incentive programs on existing and emerging economies of production.

Although this framework has proven valuable in understanding what Michael Curtin and John Vanderhoef identify as the "metatheory" of this "race to the bottom," they - alongside other media studies scholars - have called for more focused analysis of the lived reality of these broader economic patterns. ${ }^{11}$ Curtin and Vanderhoef, in considering the case of visual effects artists, argue for "adopting a multivalent approach to address the relentless and pervasive class warfare being waged against the creative workforce in Hollywood and around the world."12 One of the impacts of an increasingly globalized space of media production is an increase in contingent employment, particularly among below-the-line workers. Andrew Ross characterizes contingent laborers by "the radical uncertainty of their futures, the temporary or intermittent nature of their work contracts, and their isolation from any protective framework of social insurance." 13 As this "race to the bottom" in search of cost advantages within the media industries unfolds, more workers' employment is contingent on incentive structures that make their jobs possible. However, those structures could change in value at any moment, whether through political upheaval or through another country with better incentives changing the terms of the marketplace. Kevin Sanson, identifying location and labor as a critical 
crossroads in global film and television, explains that "media workers . . . exist in the midst of friction: facilitating it, resisting it and ever coerced by it, as a new geography of creative labor envelopes them." 14 Vicki Mayer, meanwhile, notes how these new economies of media production work as structural forces that transfer buzzwords like "dynamic, global, networked, and flexible" onto television laborers, leading to "clusters of temporary work communities [that] collaborate more sporadically for shorter-term contracts and then must migrate and remobilize."15

This second position, focused on the workers caught up in this new geography, is moving media studies scholarship toward what Mayer identifies as the "cultural geography of production," which "would not only expand our repertoire of locations but allow [media studies] to look at the location of production in relation to labor markets, capital flows, and global politics of enfranchisement." 16 It is a framework that acknowledges the political and economic concerns that often drive decision making and mark industrial progress, while simultaneously engaging with the interrelationship between those developments and the politics of labor and capital on a local level within what John Caldwell identifies as the "borderlands of production culture."17 A cultural geography of production approach asks us to consider not only the political and economic forces that lead a production to a particular location, but also the production cultures that determine how the unit functions once established in what Goldsmith, Ward, and O'Regan characterize as "local Hollywoods" in their case study of Australia's Gold Coast. ${ }^{18}$ Such production-studies work - focused on many of the regions referenced previously - has created a strong foundation for considering the impact of a newly globalized map of media production on local, regional, national, and transnational levels. ${ }^{19}$

As more focused production studies research has expanded political economic frameworks, the term runaway production in and of itself becomes limiting. As Goldsmith, Ward, and O'Regan argue, the term is misleading when attempting to speak to the realities of globally dispersed production. They note, "you cannot really describe something as running away when it is from inception 'born international.'" 20 While runaway production is a valuable macroeconomic term for considering broad, historical shifts in media production, its current utility is primarily focused on a Hollywood-centered view of media production within industry trade discourse. ${ }^{21}$ It also continues to hold purchase within the industry, evoking Allen J. Scott's reminder that those in power-studios, writers, and so forth-remain tied to the tradition of Hollywood and thus perceive production as "running away" from a centralized location. ${ }^{22}$ Within a contemporary context, runaway production presumes a center where one does not exist. Its use as a theoretical framework for considering flows of television production reinforces an outdated understanding of where television-and media more broadly-is produced both in North America and globally. Addressing the broader impact of television's expanding geography of production therefore requires a decentered model that embraces the lived dimensions of the contemporary landscape of television production. While political-economy approaches to understanding the media industries have reason to remain tied to runaway production as a key historical trend, a closer investigation of the cultural geography of production requires a new framework for considering the spatial contingencies being created for television laborers amid the "friction" Sanson identifies within the contemporary geography of creative labor. 


\section{Moving Toward Mobile Production}

In one of the few pieces to explicitly focus on runaway production's impact on television production, Scott observed in 2004 that "it may not be entirely far-fetched to speculate on a possible future scenario in which Hollywood actually starts to function within an extended spatial division of labor embodied in a world-wide patchwork of specialized production centers, though for the present its integrity as a self-sufficient cluster remains intact." 23 In the decade since his observation, increases in the number of states and provinces competing aggressively to attract television production have made this patchwork tenable. The question of where a television series will be produced has never been as open-ended as it is today.

A crucial component of this openness, and of runaway production's initial emergence, is the inherent mobility of production. Can the technology and infrastructure necessary to make a television series either be moved to a location or found in that location? While economic incentives may be the most commonly cited "pull factor" dictating a television series' production location, those incentives are only viable if the necessary infrastructure is in place. ${ }^{24}$ This is particularly true in the case of television production, which has a relationship with production mobility different from film's. Scott argues in On Hollywood that television production is more likely to be mobile due to its "relative standardized" nature as compared with film..$^{25}$ Television production, however, also requires a grander scale of infrastructure than a feature film and can carry higher stakes, given the investment being made over time. Featurefilm production is typically mobile. Individual films are in production for a finite period of time in a particular region and "the project-based character of high-budget feature films ensures that decisions are one-off decisions." 26 If there is a change in an incentive structure or if the infrastructure in a given location is found to be lacking, the producers of a film can simply choose to move their next project to a different location. By comparison, television productions set up for a much longer period and may return to a location over the course of two, five, or even ten years. They also shoot on tighter schedules and require constant adjustments as new directors adapt to a series' tone or new scripts necessitate further adjustment among local below-the-line crew or local production infrastructure.

Consequently, as states, provinces, and countries seek to lure television producers to their locations, part of their goal is replicating the infrastructure available in Los Angeles. The plethora of sound stages located in Los Angeles is one reason why television production has remained comparatively stable in California compared with film production. As Goldsmith and O'Regan observe, however, a wide range of other locations across the United States and the world are investing in similar studio infrastructure, such that "location production now means extensive or complete packages of facilities, services, and natural and built environments rather than simply being the obverse of studio-based production." 27 More recently, states such as Georgia (where UK studio Pinewood invested in its first American facility) and New Mexico (where an additional tax incentive is offered to those filming on one of the state's sound stages) have consciously expanded their studio capacities as part of an effort to replicate Hollywood infrastructure. This is part of a broader trend that has, according to Goldsmith and O'Regan, "led to the significant reduction of risks involved in location production and expanded the range of places offering infrastructure of the requisite standard." 28

This reduced risk has created an environment where a television show is no longer presumed to be shooting in Los Angeles. Rather than being pulled or pushed away from the stability of southern California, television series now enter a competitive location marketplace where any 
given television production could theoretically shoot in any given location depending on financial, logistical, and geographical considerations. This contemporary moment can therefore best be understood as one of mobile production rather than runaway production, as the "patchwork" of media capitals has evolved in such a way that it fundamentally displaces Los Angeles from the center of American television production.

While shifting to a discussion of mobile production serves the initial goal of moving away from the centered discourse of runaway production, it also works to capture the contradictory relationship between this increase in stable production locations and the rising instability of a production's relationship with a given location. As Hozic observes, "the crucial paradox of the intense competition between states and localities for investment dollars is that their attempts to differentiate themselves from each other are ultimately making them more similar." 29 Noting that "the basis of these offerings continues to consist of relatively low labor costs and the willingness to adapt to the needs of business they are trying to attract," Hozic concludes that "such produced similarities make these new sites of production far more susceptible and vulnerable to the whims of mobile businesses than they had originally set out to be." 30 While Hozic does not account for variables such as the value of local incentives, the availability of local production crew, or other components of what Goldsmith, Ward, and O'Regan term "location interest," she captures the inherent challenge of mobile television production. There is always another location offering similar - if not identical -infrastructure and labor. This means that even small shifts in a location's standing can result in mobile productions packing up for somewhere else.

As a result, in addition to speaking to the initial mobility of television productions as startup projects, mobile production as a concept also captures the ongoing mobility of television series in the contemporary moment. The Fox drama series Fringe (2008-2013) shot its pilot in Toronto before moving to New York to take advantage of the state's incentive program, but it left the city for Vancouver after the first season, when the New York incentive system began running out of money. ${ }^{31}$ MTV's Teen Wolf (2011-) filmed its first two seasons in Atlanta, Georgia, but moved production to Los Angeles after winning a tax break through California's now-defunct lottery system. ${ }^{32}$ Netflix's Hemlock Grove (2013-2015) set up a production office in Pittsburgh ahead of its first season but closed it to move production to Toronto when the conditions of the Pennsylvania tax credit system conflicted with Netflix's all-at-once release strategy. ${ }^{33}$ While one could technically consider these to be examples of productions "running away" from one location to another, focusing on the mobility of the productions reminds us that they were never in single, stable environments even after choosing initial production locations. These productions were always mobile, with producers continually tracking shifts in incentive structures and local infrastructure to determine the most efficient way to produce the series in question.

\section{Labor in an Age of Mobile Production}

A shift toward conceptualizing the industry as being in a period of mobile production expands our scale of analysis regarding those workers whose jobs are especially vulnerable in an age of production incentives. Runaway production typically has been framed as a below-the-line labor issue, both in terms of the labor benefits of production incentives and the challenges facing Los Angeles laborers as production becomes scarcer. ${ }^{34}$ Centering such perspectives on Los Angeles, however, obscures a new generation of below-the-line television laborers outside of Hollywood whose jobs were created by incentive systems and whose ability to find work is often 
dependent on the stability of production in a given state. The introduction of incentives creates a demand for local labor that is less expensive and often more incentivized than out-ofstate/out-of-province labor. As a consequence, a local labor base develops to serve as an infrastructural support for drawing ongoing production to that locality.

While small variations in the skill or size of below-the-line crew bases can play a role in decision-making tied to mobile production, their existence is ultimately dependent on the production incentives that created the labor market in a given location. As Hozic notes after considering labor in Los Angeles in light of runaway production, "the situation is equally precarious even in the places that have seemingly benefited from Los Angeles' loss of production." She specifically cites the case of Wilmington, North Carolina, which even as of 2005 had seen its film industry support "seriously questioned more than once in just over a decade." 35 If below-the-line laborers are in general contingent compared to their above-the-line counterparts, mobile production accentuates that contingency. When North Carolina dismantled its incentive program in 2014, for example, it also dismantled the support system that made it possible for many below-the-line workers to make a living in the state's film and television industry.

In the wake of the North Carolina's decision, the Hollywood Reporter reported on the outflow of production of series like Banshee and production studios like Chris Cates' C3 Studios (which he is considering moving to Georgia from Charlotte). A similar article published by Raleigh-based WRLA.com in October 2014 referenced a catering company, Luckey Craft Services, that intended to make a similar move in order to sustain business. ${ }^{36}$ Both stories also speak of individual laborers who anecdotally intend to leave the state because, put simply, they "have to go where the work is." ${ }^{37}$ Here we see evidence of how the mobility of television production pushes us to consider the mobility of television labor, or the lack thereof. Production en masse can migrate from one location to a finite but substantial number of other locations at any given moment. Below-the-line workers in locations like North Carolina must be prepared for the fact that political decisions can destroy any roots they create and that their voices-whether in formal petitions or in public advocacy statements like that of Barnhill's ${ }^{38}$ - may be marginalized because of their low standing within television production itself and within general socioeconomic hierarchies.

In this way, engaging with mobile production also means engaging with the conditions of mobile labor and the ways in which this new spatial contingency affects below-the-line workers throughout the television industry. Mobile production has impacted all forms of television labor, including above-the-line workers. Writers-more central to ongoing television production than film - primarily remain based in Los Angeles, but the job descriptions of both actors and directors have changed to include a willingness to become as mobile as television production itself. Above-the-line mobility serves to reinforce a privileged position in the production hierarchy. For below-the-line television industry workers, mobile production means being willing to move to find work, understanding that one may be moving to a location to compete against other contingent laborers who have more experience working in that geographic area.

While we can generalize that below-the-line workers are adversely affected by the circumstances of mobile production, it is important to acknowledge that not all below-the-line workers are affected in the same way. Gasher and Elmer keenly observe that "location film and television production does not mean the same thing to all industry actors, and therefore must be 
analyzed from a variety of viewpoints." 39 While a mobile production framework improves our broad understanding of production flow by expanding its investigation into the ongoing impact on below-the-line workers, it also reveals specific categories of workers whose spatialized labor is central to making mobile production viable. Location professionals offer a case study of laborers whose place within television production has been remapped significantly by mobile production, which both intensely values their labor and highlights the spatial contingencies that workers are forced to navigate in this new, unstable geography of television production.

\section{Case Study: Location Professionals}

In the trade-industry discourse dealing with the impact of changes in local production on below-the-line laborers, location professionals are consistently represented, including North Carolina location manager Brooke Barnhill, North Carolina location coordinator Christopher Courter, and Los Angeles-based location manager David Henke. ${ }^{40}$ Because mobile production is about changes in where production is located, it makes logical sense that location professionals - a category that includes location scouts, coordinators, and managers whose responsibilities are tied to finding, facilitating, and managing locations - would be among those most affected.

Although those who work in locations for a production can be broadly termed location professionals, the location scout and the location manager are the two primary roles that a location professional will be expected to perform over the course of his/her career. The location scout is described most basically as the person who goes out and finds locations for filming, or in the words of one professional, finds "the options for the director to pick where they film." 41 This description captures the way the location scout functions within the process of preproduction, whereas the location manager then takes over by securing the use of a particular location (which may involve negotiating with a homeowner or getting the necessary permits from a local government), ensuring the necessary resources are in place to film in that location, and then supervising the restoration of that location once filming is complete. One location professional referred to location managers as "the face of the production," as they are responsible for ensuring a smooth relationship with the people in and around a particular location, which is crucial to the ability for the production to operate on schedule.

When it comes to the production itself, the location manager was described by one location professional interviewed as "first one in, last one out" in each location that a production would use in a given week, or even a given day. In this way, the location manager must balance both space and time: As location professional Rebecca Puck Stair - who is based in New Mexiconotes, "it's a rolling thing, because the location manager is prepping one location while shooting in the second while cleaning up the one they shot in yesterday. You have to be able to think fluidly in time." 42

Stair has worked as a location professional on a range of film and television productions based in New Mexico. She entered the film and television industry after switching careers from English teacher to production assistant during the early days of the state's incentive system, before eventually transitioning into locations work. In order to complete this work, Stair developed an intense knowledge of the state of New Mexico over the past decade, knowledge she has been able to draw on when a production is looking for a particular type of location for a scene. Comparing location professionals to taxi drivers, Stair claims, "I pretty much know the entire state, and if you show me a picture I will tell you where it is, anywhere in that state." It's a claim that is necessary in order to be able to find locations on the short time frames offered by 
productions - particularly given the episodic turnover with television - and to ensure that those locations work logistically for the production in question. She explains that "there's some part of the location scout's brain that's always on that's off for most people most of the time, because we'll remember [a location we drive by] and exactly what it looks like, and where it was." 43 Although she officially scouts certain locations, taking photos and building a library, she also relies on these mental pictures - and on technology like Google Street View - to tap into her personal map of New Mexico and offer directors or producers a sense of her plan for a particular scene.

In this way, we can understand Stair's role as a location professional as explicitly tied to the local geography. While many other below-the-line workers, whether working in art departments or craft services, may have strong relationships with a local community, location professionals constitute one of the only groups whose primary role is developing such relationships; their labor is inherently and intricately spatial. Although the skills Stair uses to map New Mexico are common to all location professionals and ones that she could theoretically apply in a range of different states, provinces, and countries, it takes a considerable amount of time to gain the knowledge necessary to quickly and easily find a location that could serve a particular scene or double as a different location entirely. Stair presents herself as being able to complete this work quickly, not because she holds a set of skills unique among all television professionals but because of the locality of her skills within New Mexico, gained through personal experience scouting and managing locations in the state.

The emergence of workers like Stair has been crucial to enabling locations like New Mexico to benefit from the increased mobility of television production. Their labor replicates established location-based production cultures present in Los Angeles. Michael John Meehan, a location professional who began his career working in television in Los Angeles before branching out into global film production, describes working in Los Angeles in the mid-1980s as a "plug-andplay" environment. ${ }^{4} \mathrm{He}$ explains that he would "run around to try to find a mansion and knock on the door and [hear] 'there's my agent's number.' Aw jeez-[I] might as well have just looked through the books." He described books filled with potential locations, to which he noted that many location professionals contributed, and containing "the usual suspects: where do you find this, where do you find that, who owns this, all that kind of stuff. That used to be the calling card of Los Angeles." A producer whose sitcom shoots Los Angeles for New York refers to location professionals as "unsung heroes" and whose knowledge of the city has given them quick and efficient access to locations in downtown Los Angeles that successfully stood in for Brooklyn when they needed something beyond the scale available on a backlot, and that have likely stood in for Brooklyn on other shows with the same idea in mind.

Meehan, reflecting on the rise in production outside of Los Angeles, observes, "That's what [other cities] would do too-just show and tell. Where can you shoot New York? Where can you shoot the usual suspects there?" While discussing her ability to serve as a local expert, Stair confirms this: "I can quite quickly think of doubles" and the distinct challenges between "landscape for landscape doubling" - which would be common on a New Mexico-filmed series like A\&E's Longmire (2012-), which is set in Montana - and "city-for-city doubling." She argues that the former is more challenging "because we tend to hold the camera wider and be closer to 360 degrees if we can. It's easier to cheat an urbanscape with an interior or a city block-you need fewer degrees of sellability to make it work." 45 That Stair positions her work in the terms of doubling indicates the degree to which her knowledge has been framed not simply in terms of places that would be ideal for shooting, but also in terms that translate those locations into 
practical vocabulary expected by producers, vocabulary that emulates the type of institutional knowledge that has existed in Los Angeles for decades.

The labor of location professionals is a crucial component that allows television production which, due to its longer production duration, tends to require an exceptionally varied and extensive collection of locations - to become mobile. Although mobile production relies on a strong crew base representing all forms of below-the-line television labor, location professionals play a vital role in demonstrating the feasibility of mobile production. ${ }^{46}$ This is particularly true given the increased demand for city-for-city doubling created through mobile production. Although a series may wish to move production from one state to another, its producers do not necessarily want to change where a series is set, creating situations like ABC's Killer Women (2013). The crime procedural, which focused on a Texas Ranger played by Tricia Helfer, shot its pilot in Austin, Texas but moved production to Albuquerque, New Mexico. This required Stair - as the location manager - to find locations in Albuquerque that could double for Austin. It was her first ongoing television series and came with a set of challenges distinct from her previous film work. Reflecting on her experience, she observed,

It's harder to get away with things. In a feature, if one location doesn't quite work - first, you have more resources in terms of time and money, that kind of thing. And if one particular scene doesn't exactly sell itself, it's okay, because you're not coming back there. It's like sleight of hand-they never do the same trick twice, because people will catch on. But in television, you have episodic characters, and you never know if we're coming back to a location. We don't know, because scripts are coming out as we're filming, so the standards are higher for finding believable locations. ${ }^{47}$

Although Stair speaks to the general challenges of finding believable locations - which could include passing off one type of building as another-she is specifically confronting the challenge of city-for-city doubling Albuquerque for Austin. Acknowledging that this made locations more challenging than if the series had-like Breaking Bad (2007-2013) - been set in Albuquerque, Stair notes, "at the beginning of the season we found a lot of locations and we had our pick. But by the end of the season, by episode 8 , we really had to stretch ourselves to see what we could get away with."

Here Stair positions herself as one of the central figures - alongside the production designer and director-in ensuring that the creative goals of the production are not sacrificed due to its embrace of mobile production logics. Without a location team capable of finding doubles on a hectic television schedule, the production would be forced to accept a lesser standard of cityfor-city doubling or move the production to Texas and sacrifice the incentives. In fact, this move would have been a possibility had Killer Women been picked up for a second season. Reflecting on the challenges the team faced toward the end of the season, Stair explains, "the consensus on the crew was that if there was a season 2, it would have been extraordinarily difficult to continue to cheat and film it in New Mexico. We and the production designer agreed that we really needed to go to Texas to pull it off again."

\section{The Immobility of Locations Labor}

The case of Stair's work on Killer Women reinforces the inherent spatiality of location professionals' labor. While all workers who live and work in a particular location share a relationship with the local area, the specific dimensions of locations work make professionals 
like Stair central to facilitating the ongoing demands of mobile television production. Belowthe-line positions are to different degrees spatialized in the period following the introduction of an incentive system. While set decorators and casting directors develop strong relationships with local businesses or talent pools, respectively, technical laborers primarily develop skills that are less distinctly tied to the local dimensions of production. As a result, their abilities to mobilize vary, such that the instability of mobile production impacts them differently.

Location professionals offer an extreme case, as their skills are almost exclusively tied to the geography of television production. Although there are basic attributes that make someone a good location professional, Stair's experience reinforces that their greatest asset is knowledge of a city, state, or region, a process that requires considerable time and experience. Their livelihoods are thus more vulnerable than many other workers when a state like North Carolina's incentive system is put into a position of political uncertainty. Lighting technicians or camera operators on a series like Under the Dome, for example, might have to make personal sacrifices in order to make their labor mobile if they wished to continue working on the series should it leave the state. In contrast, location manager Brooke Barnhill would also have to sacrifice long-standing relationships with the local community and her knowledge of local geography, only to replicate, at great effort, that knowledge in other locations if she wished to remain part of the series (or, based on the outflow following the change in the state's incentive structure, any television series). Under the Dome location coordinator Christopher Courter describes location workers as "rel[ying] heavily on a familiarity with the region. You can't just move to a place and have that knowledge. It takes time to build that base of information." 48 This means that even if a North Carolina-based television production was willing to allow its workers to become mobile to follow the project to Georgia or Louisiana, Courter and other location professionals would be unable to quickly replicate their knowledge base in the new location, likely leading the production to hire new local location professionals with greater knowledge of the new production location.

Although any worker who has a family or is tied to a particular location for other reasons has a stake in the politics of production incentives, this is particularly true for location professionals: Stair, who in May of 2014 became a board member of the advocacy-focused Location Managers Guild of America, argues,

Part of my job is being political [and] being in contact with my legislators, educating them about what the film industry does and who I am and how it's benefited me, and how it's benefited the state. I consider that as my job when I'm not working on a project. ${ }^{49}$

Although not all location professionals are as politically engaged, they are more keenly aware than most about the political side of incentive structures. This is because their work is closely tied to the geography on which those incentives are mapped by the studios producing content, and because they work closely with local film commissions to complete day-to-day labor. They also spend a great deal of time in the local community and are thus valuable lobbyists for the broader impact of incentives. As Barnhill emphasizes in her profile in the Wilmington Star News, "It is not just about the film crew. We employ officers at these locations, we help make donations at local schools and churches, and families benefit from the work." 50 Barnhill's profile represented a conscious lobby to the North Carolina legislature, which was currently determining the future of their incentive program. It did not come from a politician or a highlevel studio executive. It came from a below-the-line laborer whose understanding of her own 
relationship to place was transformed by the spatial contingencies of an era of mobile production.

\section{Conclusion}

In October 2014, CBS announced that it was renewing Under the Dome for a third season, production of which would remain in Wilmington, North Carolina. The decision was a surprise, given that CBS would be unable to enjoy the incentives received in previous years based on the state's change to a capped grant program. CBS Television Studios executive Kevin Berg called returning "a pleasure," and noted that "the film community in the state, and particularly in the greater Wilmington area, is simply outstanding." 51

While Under the Dome's decision to stay might imply that North Carolina location professionals like Brooke Barnhill could rest easy, the circumstances of mobile production outlined in this article suggest otherwise. To characterize television production as mobile is to characterize the location of any given project as tenuous. Any show is able to move to another location between seasons or between pre-production and production. For contingent laborers whose livelihoods are tied to the development of local production communities like Wilmington's, the increasing number of such communities across North America-and the world-and the continued fluctuation in the incentive structures supporting them means that there is no pretense of stability within contemporary television production in light of these spatial contingencies.

We can therefore understand mobile production as an environment that incentivizes, and in some cases requires, mobile labor, even for workers like location professionals, for whom mobilizing is an extreme burden. New Mexico location scout Stair argues that mobilizing her labor, although difficult, is a requirement for someone in her line of work. Currently she is trying to develop her knowledge of locales outside of New Mexico as a hedge against the possibility that the politically controversial state incentives could disappear. Yet her decision to stick with location work has been a tough one. "That's my choice," she confides, "and my personal family situation. Many other crew will also have to choose between the work they love and the place they love."

For now, there are no clear signs that New Mexico's incentive system is in jeopardy, but location managers have reason to diversify the geography of their labor even without a looming crisis. While a location manager's value has expanded considerably in an era of mobile production and local production incentives, that value is tied to compendiums of rich local knowledge that are not transferrable when the flow of mobile television production shifts toward other locations. The experience of location professionals in this period of mobile production makes the spatialized dimensions of contemporary television starkly visible, revealing how the relocation of television production has remapped the contingencies facing those whose labor facilitates that relocation.

${ }^{1}$ Myles McNutt is a PhD candidate in Media and Cultural Studies at the University of Wisconsin-Madison's Department of Communication Arts, and starting in Fall 2015 will be Assistant Professor of Communication and Theatre Arts at Old Dominion University. $\mathrm{He}$ is Administrator and Contributing Editor for Antenna: Responses to 
Media and Culture, a contributing writer for The A.V. Club, and author of Cultural Learnings. In addition to email, he can be reached via Twitter or Tumblr.

${ }^{2}$ Hunter Ingram, "“Under the Dome' Location Manager Always Looking for a PLACE," Star News Online, July 20, 2014.

3 See Hunter Ingram, "A Wrap for 'Dome,'” Star News Online, July 18, 2014; Hunter Ingram, "Burgaw, Southport, Wilmington Offer Scenery for 'Under the Dome,'" Star News Online, June 22, 2014.

${ }^{4}$ Hunter Ingram, "Grant Program Darkens Chances for TV Series, Indie Productions in N.C.," Star News Online, August 13, 2014.

5 Pittsburgh Film Office head Dawn Keezer, quoted in Rob Owen, "Pittsburgh-Set TV Series 'Hemlock Grove' Pulls Out a Month before Filming," Pittsburgh Post-Gazette, May 11, 2012.

6 Peter Hall, “The Dream Factory: Los Angeles 1910-1945," in Cities in Civilization (New York: Pantheon Books, 1998), 520-52; Greg Elmer and Mike Gasher, "Introduction: Catching Up to Runaway Productions" in Contracting Out Hollywood: Runaway Productions and Foreign Location Shooting (Lanham, MD: Rowman and Littlefield, 2005), $1-20$.

7 Toby Miller et al., Global Hollywood 2 (London: British Film Institute, 2005), 7.

8 Aida A. Hozic, Hollyworld: Space, Power, and Fantasy in the American Economy (Ithaca, NY: Cornell University Press, 2001), 112.

${ }_{9}^{9}$ Miller et al., Global Hollywood 2, 171.

10 See Allen J. Scott, On Hollywood: The Place, the Industry (Princeton, NJ: Princeton University Press, 2005); Susan Christopherson and Jennifer Clark, Remaking Regional Economies: Power, Labor, and Firm Strategies in the Knowledge Economy (New York: Routledge, 2007); Amelia Hurt, "Hollywood on the Bayou: An Optimal Tax Approach to Evaluating and Reforming the Louisiana Motion Picture Investor Tax Credit," Louisiana Law Review 74 (2014): 581-612; Cathy Yang Liu, Ric Kolenda, Grady Fitzpatrick, and Tim N. Todd, "Re-Creating New Orleans: Driving Development through Creativity," Economic Development Quarterly 24, no. 3 (2010): 261-75; Stephen R. Miller and Abdul Abdulkadri, The Economic Impact of Michigan's Motion Picture Production Industry and the Michigan Motion Picture Production Credit (Lansing: Center for Economic Analysis Michigan State University, 2009); John E. Connaughton and Ronald A. Madsen, "The Economic Impact of the Film and Video Production and Distribution Industry on the Charlotte Regional Economy," Journal of Business and Economics Research 9, no. 4 (2011): 15-26.

${ }^{11}$ Michael Curtin and John Vanderhoef, "A Vanishing Piece of the Pi: The Globalization of Visual Effects Labor," Television and New Media 16, no. 3 (2015): 220.

12 Ibid., 221.

${ }^{13}$ Andrew Ross, Nice Work If You Can Get It: Life and Labor in Precarious Times (New York: New York University Press, 2010), 6.

14 Kevin Sanson, "Location and Labor: Critical Crossroads in Global Film and Television," Creative Industries Journal 7, no. 1 (2014): 57.

15 Vicki Mayer, Below the Line: Producers and Production Studies in the New Television Economy (Durham, NC: Duke University Press, 2011), 177.

16 Vicki Mayer, “Where Production Takes Place," Velvet Light Trap 62 (2008): 71. 
17 See also John T. Caldwell, "Industrial Geography Lessons: Socio-Professional Rituals and the Borderlands of Production Culture," in MediaSpace: Place, Scale, and Culture in a Media Age, ed. Nick Couldry and Anna McCarthy (London: Routledge, 2003), 164.

18 Ben Goldsmith, Susan Ward, and Tom O'Regan, Local Hollywood: Global Film Production and the Gold Coast (Queensland: University of Queensland Press, 2011).

${ }^{19}$ For an example of work that has followed this model in analyzing local production cultures supported by incentives, see Serra Tinic, On Location: Canada's Television Industry in a Global Market (Toronto: University of Toronto Press, 2005); further work in this area can be found in "Part III: Production Spaces: Centers and Peripheries," in Production Studies: Cultural Studies of Media Industries, ed. Vicki Mayer, Miranda J. Banks, and John T. Caldwell (New York: Routledge, 2009), 123-72.

${ }^{20}$ Goldsmith, Ward, and O'Regan, Local Hollywood, 25.

21 This was most recently evident in trade discourse in discussions surrounding the state of California's own tax credit system. See Tina Daunt, “L.A. Mayor Eric Garcetti Calls Runaway Film Production a Civic 'Emergency,'”' Hollywood Reporter, July 2, 2013; Ted Johnson, "Governor, Legislative Leaders Reach Deal on California Film and TV Tax Credit," Variety, August 27, 2014,.

22 Allen J. Scott, "The Other Hollywood: The Organizational and Geographic Bases of Television-Program Production," Media Culture and Society 26, no. 2 (2004): 183-205.

23 Scott, "The Other Hollywood," 202.

${ }^{24}$ Goldsmith, Ward, and O'Regan, Local Hollywood. 3.

25 Scott, On Hollywood, 55.

26 Ben Goldsmith and Tom O'Regan, The Film Studio: Film Production in the Global Economy (Lanham: Rowman and Littlefield, 2005), 13.

27 Ibid., 6.

${ }^{28}$ Richard Verrier, "Pinewood Studios Expands into Georgia," Los Angeles Times, April 29, 2013; Todd Longwell, "Tax Incentives Build Thriving Production Culture in New Mexico," Variety, August 14, 2014; Goldsmith and O'Regan, The Film Studio, 10.

${ }^{29}$ Hozic, Hollyworld, 120.

30 Ibid., 121.

${ }^{31}$ David Fleischer, "Reel Toronto: The Fringe Pilot," Torontoist, January 2, 2014; Dave Itzkoff, "As New York Tax Credits Disappear, So Does Fox's 'Fringe,'” New York Times, February 24, 2009.

32 Richard Verrier, “'Teen Wolf' Transforms into an L.A. Production," Los Angeles Times, December 12, 2012, 2.

33 Rob Owen, “Pittsburgh-Set TV Series 'Hemlock Grove' Pulls Out a Month before Filming," Pittsburgh Post-Gazette, May 11, 2012.

${ }^{34}$ See, for instance, Richard Verrier, "Los Angeles Losing the Core of Its TV Production to Other States," Los Angeles Times, August 15, 2012.

35 Hozic, Hollyworld, 117-18.

${ }^{36}$ Mike Binker, "NC's Film Industry Shaken as Incentive Program Shifts," WRAL.com, October 13, 2014.

37 Alex Ben Block, “North Carolina Kills Film Incentives: Which States Benefit?" Hollywood Reporter, August 22, 2014.

38 Hunter Ingram, "'Under the Dome' Location Manager."

${ }^{39}$ Elmer and Gasher, Contracting Out Hollywood, 2. 
${ }^{40}$ Courter, who worked on Under The Dome alongside Barnhill, was featured in the photo accompanying Hunter Ingram, "'Dome' Crew Faces Dim Outlook as Season Finale Set to Air," Star News Online, September 19, 2014.

41 These and other stated observations derive from personal interviews conducted with location professionals in 2014.

42 Personal interview, March 11, 2014.

43 Personal interview, March 11, 2014.

44 Personal interview, March 30, 2014.

45 Personal interview, March 11, 2014.

${ }^{46}$ Locations work is also integrated into the work of regional film offices in helping support city-for-city doubling and mobile location production, as outlined by Pacey Foster, Stephan Manning, and David Terkla, "The Rise of Hollywood East: Regional Film Offices as Intermediaries in Film and Television Production Clusters," Regional Studies 49, no. 3 (2015): 433-50.

47 Personal interview, March 11, 2014.

48 Ingram, "'Dome Crew Faces Dim Outlook."

49 Personal interview, March 11, 2014.

50 Ingram, "'Under the Dome'"

${ }^{51}$ Dave McNary, "“Under the Dome' Staying in North Carolina for Season 3," Variety, October 10, 2014.

\section{Bibliography}

Banks, Paul. "Production Guild: Location Manager Training," The Knowledge, last modified June 6, 2014.

Binker, Mike. "NC's Film Industry Shaken as Incentive Program Shifts," WRAL.com, last modified October 13, 2014.

Block, Alex Ben. “North Carolina Kills Film Incentives: Which States Benefit?” Hollywood Reporter, August 22, 2014.

Caldwell, John T. “Industrial Geography Lessons: Socio-Professional Rituals and the Borderlands of Production Culture." In MediaSpace: Place, Scale, and Culture in a Media Age, edited by Nick Couldry and Anna McCarthy, 163-89. London: Routledge, 2003.

Christopherson, Susan, and Jennifer Clark. Remaking Regional Economies: Power, Labor, and Firm Strategies in the Knowledge Economy. New York: Routledge, 2007.

Connaughton, John E., and Ronald A. Madsen. "The Economic Impact of the Film and Video Production and Distribution Industry on the Charlotte Regional Economy." Journal of Business and Economics Research 9, no. 4 (2011): 15-26.

Curtin, Michael, and John Vanderhoef. "A Vanishing Piece of the Pi: The Globalization of Visual Effects Labor." Television and New Media 16, no. 3 (2015): 219-39. 
Daunt, Tina. “L.A. Mayor Eric Garcetti Calls Runaway Film Production a Civic 'Emergency.'” Hollywood Reporter, July 2, 2013.

Elmer, Greg, and Mike Gasher, eds. Contracting Out Hollywood: Runaway Productions and Foreign Location Shooting. London: Rowman and Littlefield, 2005.

Fleischer, David. “Reel Toronto: The Fringe Pilot." Torontoist, January 2, 2014.

Foster, Pacey, Stephan Manning, and David Terkla. “The Rise of Hollywood East: Regional Film Offices as Intermediaries in Film and Television Production Clusters." Regional Studies 49, no. 3 (2015): 433-50.

Gasher, Mike. Hollywood North: The Feature Film Industry in British Columbia. Vancouver: University of British Columbia Press, 2002.

Goldsmith, Ben, Susan Ward, and Tom O'Regan. Local Hollywood: Global Film Production and the Gold Coast. Queensland: University of Queensland Press, 2011.

Goldsmith, Ben, and Tom O'Regan. The Film Studio: Film Production in the Global Economy. London: Rowman and Littlefield, 2005.

Hall, Sir Peter. Cities in Civilization. New York: Pantheon Books, 1998.

Hozic, Aida A. Hollyworld: Space, Power, and Fantasy in the American Economy. Ithaca, NY: Cornell University Press, 2001.

Hurt, Amelia. "Hollywood on the Bayou: An Optimal Tax Approach to Evaluating and Reforming the Louisiana Motion Picture Investor Tax Credit." Louisiana Law Review 74 (2014): 581-611.

Ingram, Hunter. “A Wrap for ‘Dome.'” Star News Online, July 18, 2014.

- - -. "Burgaw, Southport, Wilmington Offer Scenery for 'Under the Dome.'” Star News Online, June 22, 2014.

- -. “'Dome Crew Faces Dim Outlook as Season Finale Set to Air." Star News Online, September 19, 2014.

- - - "Grant Program Darkens Chances for TV Series, Indie Productions in N.C." Star News Online, August 13, 2014. http:// www.starnewsonline.com/article/20140813/ARTICLES/140819864/1177?Title $=$ Grant-program-darkens-chances-for-TV-series-indie-productions-in-N-C.

- - -. "'Under the Dome' Location Manager Always Looking for a Place." Star News Online, July 20, 2014.

Itzkoff, Dave. “As New York Tax Credits Disappear, So Does Fox's 'Fringe.'” New York Times, February 24, 2009. 
Johnson, Ted. “Governor, Legislative Leaders Reach Deal on California Film and TV Tax Credit." Variety, August 27, 2014.

Liu, Cathy Yang, Ric Kolenda, Grady Fitzpatrick, and Tim N. Todd. "Re-creating New Orleans: Driving Development Through Creativity." Economic Development Quarterly 42, no. 3 (2010): 261-75.

Longwell, Todd. "Tax Incentives Build Thriving Production Culture in New Mexico." Variety, August 14, 2014.

Mayer, Vicki. Below the Line: Producers and Production Studies in the New Television Economy. Durham, NC: Duke University Press, 2011.

- - -. “Where Production Takes Place." Velvet Light Trap 62 (2008): 71-72.

Mayer, Vicki, Miranda J. Banks, and John T. Caldwell, eds. Production Studies: Cultural Studies of Media Industries. New York: Routledge, 2009.

McNary, Dave. "“Under the Dome' Staying in North Carolina for Season 3." Variety, October 10, 2014.

Miller, Steven R., and Abdul Abdulkadri. The Economic Impact of Michigan's Motion Picture Production Industry and the Michigan Motion Picture Production Credit. Lansing: Center for Economic Analysis, Michigan State University, 2009.

Miller, Toby, Nitin Govil, John McMurria, Richard Maxwell, and Ting Wang. Global Hollywood 2. London: British Film Institute, 2005.

Owen, Rob. "Pittsburgh-Set TV Series 'Hemlock Grove' Pulls Out a Month before Filming." Pittsburgh Post-Gazette, May 11, 2012.

Ross, Andrew. Nice Work If You Can Get It: Life and Labor in Precarious Times. New York: New York University Press, 2009.

Sanson, Kevin. "Location and Labor: Critical Crossroads in Global Film and Television." Creative Industries Journal 7, no. 1 (2014): 54-58.

Scott, Allen J. On Hollywood: The Place, the Industry. Princeton, NJ: Princeton University Press, 2005.

- - - "The Other Hollywood: The Organizational and Geographic Bases of TelevisionProgram Production." Media Culture and Society 26, no. 2 (2004): 183-205.

Tinic, Serra. On Location: Canada's Television Industry in a Global Market. Toronto: University of Toronto Press, 2005.

Verrier, Richard. “Los Angeles Losing the Core of Its TV Production to Other States." Los Angeles Times, August 15, 2012. 


\section{- - -." "Teen Wolf' Transforms into an L.A. Production.” Los Angeles Times, December 12, 2012.}

- - - "Pinewood Studios Expands into Georgia." Los Angeles Times, April 29, 2013.

\section{$(\mathrm{Cc}) \overline{\mathrm{BY}-\mathrm{NC}-\mathrm{ND}}$}

Copyright ( $) 2015$ (Myles McNutt). Media Industries is an open-access, peer-reviewed, online academic journal. As such, we aim to participate in the open exchange of information. This work is licensed under a Creative Commons Attribution Noncommercial No Derivatives (by-nc-nd) License. Under this license, this work is available for sharing and noncommercial distribution provided the appropriate attribution is given. 